\title{
MINERAL RESOURCE POTENTIAL OF THE HOOVER WILDERNESS AND ADJACENT ROADLESS AREAS, CENTRAL SIERRA NEVADA, CALIFORNIA
}

\section{SUMMARY REPORT}

\author{
By
}

Edwin W. Tooker ${ }^{1}$, Nicholas T. Zilka ${ }^{2}$, Maurice A. Chaffee ${ }^{1}$,Donald Plouff ${ }^{1}$,
Gerald F. Brem ${ }^{1}$, william J. Keith ${ }^{1}$, James F. Seitz ${ }^{1}$, and A. M. Leszcykowski

\section{STUDIES RELATED TO WILDERNESS}

Under the provisions of the Wilderness Act (Public Law 88-577, September 3, 1964) and related acts, the U.S. Geological Survey and the U.S. Bureau of Mines have been conducting mineral surveys of wilderness and primitive areas. Areas officially designated as "wilderness", "wild", or "canoe" when the act was passed were incorporated into the National Wilderness Preservation System, and some of them are presently being studied. The act provided that areas under consideration for wilderness designation should be studied for suitability for incorporation into the Wilderness System. The mineral surveys constitute one aspect of the suitability studies. The act directs that the results of such surveys are to be made available to the public and be submitted to the President and the Congress. This report discusses the results of a mineral survey of the Hoover Wilderness and Cherry Creek A, Hoover Extension (East), Hoover Extension (West), and Leavitt Lake Roadless Areas, Toiyabe, Stanislaus, and Inyo National Forests, Mono and Tuolumne Counties, California. Hoover Wilderness was established by Public Law 88-577, September 3, 1964. Cherry Creek A (5-662) Roadless Area was classified as a further planning area and Hoover Extension (East) (E4662), Hoover Extension (West) (W4-662), and Leavitt Lake (4-666) Roadless Areas were classified as recommended wilderness areas during the Second Roadless Area Review and Evaluation (RARE II) by the U.S. Forest Service, January 1979.

\section{SUMMARY}

Resource studies of the Hoover Wilderness and adjoining roadless areas, California, indicate a resource potential for gold and tungsten deposits; a porphyry copper-molybdenum occurrence is also inferred. Evaluation of the study area is based on a search of mining and production records, on examination of known mines, claims, and prospects, and on geologic, geochemical, and geophysical surveys.

Gold deposits, some mined as early as 1871 , are located in the southern half of the wilderness and adjoining study area in the Lundy Canyon, Virginia Lakes, Glines Canyon, and Dunderberg Creek areas. Small tungsten deposits are known in the Cherry Creek area (area 5-662) and in the southwestern part of the Hoover Wilderness. U.S. Bureau of Mines records, although believed incomplete, indicate a total production of at least 42,500 troy ounces of gold and 18,000 oz of silver, mainly from the May Lundy mine. Production of tungsten in the wilderness was small. Known gold and tungsten resource potential occurs in extensions of known deposits (table 2), mainly at six mines or properties. The resource potential at any single mine is limited, owing to the small size and sparse occurrence of high-grade ore shoots in veins along shear surfaces or in lens-shaped bodies of shallow depth in metesediments. Any future production in the study area will be limited by difficult access and by special requirements for mining and milling that are necessary to protect the environment.

Assessment of geologic, geochemical, and geophysical resource-favorability attributes of the study areas has identified terranes (table 1) that have untested resource potential in addition to or adjoining those already known. A ranking of these favorability characteristics indicates that gold resources are present in varying amounts in the study area and that the tungsten resource potential is small. Confirmation of a possible buried disseminated copper and molybdenum occurrence at the north end of the area (Tooker and others, 1981) will require additional detailed geologic studies and subsurface exploration. The potential for conventional types of base-metal and uranium occurrences in and near the study area is considered low. There are no known sources of geothermal or fossil fuel energy in the study area, and so the energy potential must be considered low.

\section{INTRODUCTION}

\section{Location, geography, and access}

The Hoover Wilderness and adjoining roadless areas lie along and immediately east of the crest of the Sierra Nevada, in Mono and Tuolumne Counties, east-central California. The areas studied are located mostly in the Toiyabe National Forest, but small parts extend into the Stanislaus and Inyo National Forests. An elongate northwest-trending narrow orea (fig. 1), the Hoover Wilderness, is about $31 \mathrm{mi}$ in length and ranges irregularly in width from 1.2 to $18.6 \mathrm{mi}$, enclosing approximately 159,000 acres. On the west, the Hoover Wilderness and adjacent roadless areas border the Emigrant Wilderness and Yosemite National Park. The east side of the area is bounded by Bridgeport Valley, Mono Lake, and tribu- taries of the West Walker River. Elevations range from $12,000 \mathrm{ft}$ along the crest of the Sierra Nevada to $6,450 \mathrm{ft}$ at the Bridgeport Reservoir spillway. This is a region of marked relief and spectacular scenery that has been enhanced by glacial erosion. Access to the wilderness is by two paved highways that cross the Sierra Nevada, at Sonora Pass on the north and Tioga Pass on the south, and by a number of spur roads from the east side, as well as numerous foot trails.

\section{Purpose}

The objectives of this study are (1) to make an evaluation of known mineral deposits and mineral occurrences, (2) to assess the geologic possibilities for finding undiscovered mineral resources, and (3) to evaluate the mineral resource potential for the area. Field studies were

${ }_{2}^{1}$ U.S. Geological Survey

2 U.S. Bureau of Mines 
conducted by the U.S. Geological Survey and U.S. Bureau of Mines to provide a data base to meet these objectives.

\section{Past and present mining activity and production}

Prospecting and mining in this region began in the Jordan mining district, east of Lundy Canyon, and the Mono mining district, south of Tioga Pass, during the late 1850's (DeDecker, 1966). Land records of Mono and Tuolumne Counties indicate that approximately 1,100 mining claims, including 9 patented claims, have been located in the area of study since 1859; however, many are relocations of previous claims. Prospectors staked claims near Castle Peak (Dunderberg Peak, area E4-662) in 1867 and later organized the Castle Peak mining district. In 1878, the Tioga mining district was organized near Tioga Pass, about $3 \mathrm{mi}$ south of the study area. The Homer mining district was organized in 1879 after gold was discovered on Mount Scowden near Lundy Canyon.

Production in the area began in 1871 at the Dunderberg mine $(17,20)^{3}$, near Castle Peak. In 1881 , the Great Sierra Consolidated Silver Mining Company, holding a group of claims near Tioga Pass, drove an adit to crosscut the Sheepherder vein. The adit was driven for a total length of $1,800 \mathrm{ft}$ without intersecting the vein, and work was discontinued in 1884. Gold-bearing veins on Mount Scowden were also being developed at this time, and a considerable amount of ore was extracted from the May Lundy (60), Gorilla (38, 45), Homer (36, 37, 42-44), Parrett, Golden Prince (57), and Gray Eagle-Mono (39) mines. By 1884, mining had decreased as less promising and less productive properties were abandoned. Production continued until 1938 in the May Lundy, to 1904 in the Golden Prince, and to 1899 in the Dunderberg mines.

Total production from area mines is difficult to determine because complete production records do not exist; however, the data available provide a measure of the relative magnitude of production. U.S, Bureau of Mines records show that more than 41,000 tons ${ }^{4}$ of ore were mined yielding 42,500 oz of gold and 18,000 oz of silver. Other reports indicate that the total production exceeded 128,000 tons of ore worth $\$ 2,900,000$ at the time of production (gold at $\$ 20.67 / \mathrm{oz})$. Most of this production was from the May Lundy mine.

Scheelite (CaWO $)$ deposits were explored in the 1940's at the Hess mine (61-63) in the Hoover Wilderness, and in the 1950 's and 1960 's on the High Sierra Scheelite (4), Buckskin (5), Bigelow (6), Montezuma (8), and Snow Lake (7) claim groups in the Cherry Creek A Roadless Area (5-662), which was described by Fillo (Tooker and others, 1970). Tungsten production was small.

Current mineral industry interest is centered on precious-metal deposits in or near the southern part of the Hoover Wilderness. Exploration to determine the extent and grade of gold resources at the May Lundy mine (60) is being conducted by Minerals Management, Inc. Small-scale gold mining is underway at the Totland mine (28-31) and in several other localities.

\section{Previous geologie studies}

The geology of the region has been the subject of numerous investigations. Clyde Wahrhaftig (written commun., 1981) mapped the northwestern part of the study area along the Sierra Nevada crest in and adjacent to the Emigrant Wilderness, an area described and evaluated by Tooker and others (1970). A geologic map of the Matterhorn Peak 15-minute quadrangle by Chesterman (1975) covers much of the central part of the Hoover area. Reports by Brook (1977) and Kistler (1966) in part discuss the geology of the southernmost portion of the Hoover Wilderness. The regional geologic setting of the batholithic and voleanic rocks and their geochronology in this part of the central Sierra Nevada are described by Bateman and Wahrhaftig (1966), Slemmons (1966), Evernden and Kistler (1970), Noble and others (1974), and Silberman and McKee (1977). The geophysical (magnetic) framework of this region has been characterized by Zietz and Kirby (1960). There is no previous comprehensive regional geochemical sum mary.

\section{Present resource studies}

Field studies were made by the U.S. Geological Survey and U.S. Bureau of Mines in 1977 and 1978, mainly by foot traverses supported by four-wheel-drive vehicles and helicopters. The U.S. Bureau of Mines studies were directed by N.T. Zilka (Zilka and Leszcykowski, 1982); the detailed data from these studies are in an as yet unpublished U.S. Bureau of Mines Mineral Land Assessment File Report. Geologic studies were coordinated by E. W. Tooker, and reports prepared from these studies are cited.

\section{Acknowledgments}

Scientific and support contributions are recognized individually in the reports listed in the following sections of this report. We also appreciate the cooperation of the regional managers of the Toiyabe, Inyo, and Stanislaus National Forests. The U.S. Geological Survey is particularly indebted to Mr. Gary Sayers of the Bridgeport District Ranger Station for logistical and other support provided during field studies, to helicopter pilot Pat Donovan, Carson City, Nev., for assistance in gaining access to the area, and to Mr. and Mrs. Lynn Nearpass for personal kindnesses and for the use of their camp and heliport facilities. The U.S. Bureau of Mines is grateful to the Bancroft Library, University of California, Berkeley, for access to reports and other documents relating to the mining districts and to property owners Benton Bailey, Emmett Dahl, and George Totland for assistance and information.

\section{EVALUATION OF KNOWN RESOURCES}

\section{By N. T. Zilka and A. M. Leszeykowski}

\section{scope of the evaluation}

The evaluation of known mineral resources in the study area is based on a search of courthouse and library records, personal interviews, and field examinations. Examination of records of claims and mineral deposits in Mono and Tuolumne Counties and in the published literature was followed, where possible, by interviews with claim owners. Field studies consisted of locating and visiting known mines, claims, and prospects. The prospects were sampled, and all major mines were mapped. Four hundred sixty-five samples were analyzed to determine the probable maximum metal content at a particular site; most samples weighed from 5 to $10 \mathrm{lb}$ and were obtained by chipping across veins, mineralized zones, and altered zones. Where workings were caved, mineralized rock was sampled randomly from the dump. All samples were analyzed for gold and silver by fire assay. Other metallic elements were determined by atomic-absorption, colorimetric, or X-ray fluorescence methods (Zilka and Leszcykowski, 1982). Some samples were analyzed for 43 elements by a semiquantitative spectrographic method by the U.S. Bureau of Mines metallurgical laboratory, Reno, Nev.

\section{Mines, prospects, and mineralized areas}

Mineral deposits located on the map are geologically similar to significant deposits elsewhere in the Sierra Nevada and are mainly of the vein and contact skarn types. The veins, which are spatially and genetically related to granitic

\footnotetext{
${ }^{3}$ Numbers in parentheses refer to map locations.

4 Production units used: ton, short ton(s); oz, troy ounce(s).
} 
intrusions, occur as fissure fillings in both metamorphic and intrusive rocks. Trending predominantly north-northwest, the veins pinch, swell, split, and branch; more than one episode of deformation has caused some vein dislocations. The veins are composed mainly of quartz and country rock breccia, and locally they contain gold. Pyrite and arsenopyrite commonly are present, and galena, chalcopyrite, sphalerite, and molybdenite occur sporadically. Gold placers derived from the veins do not occur inside the study area, but several were mined just outside. Contact metasomatic (skarn) tungsten deposits consist of altered scheelite-bearing calc-silicate hornfels and epidote-garnet tactite adjacent to some intrusions. The scheelite is disseminated along discontinuous shoots. Minor amounts of molybdenite occur locally in the skarns.

\section{Hoover Wilderness}

The southern part of the Hoover Wilderness has the highest mineral potential of the five areas studied. About 560 claims have been staked within and near it. The most significant property, both in terms of past production and resource potential, is the May Lundy (60). Between 1870 and 1938 , its gold production totaled $\$ 2.8$ million ${ }^{5}$, estimated to be about $135,000 \mathrm{oz}$. Because funds were depleted during a development stage, the May Lundy mine ceased operations before being mined out. Since 1938, several companies have considered reopening the mine. Gold price increases have caused renewed industry interest in the property. Although several veins occur within the claim group, only the May Lundy vein is large and well mineralized. The vein is exposed in the workings for $3,040 \mathrm{ft}$ horizontally and $2,100 \mathrm{ft}$ downdip. Average width is 30 in. Measured, indicated, and inferred ore reserves are estimated to be 344,300 tons, with gold content averaging $0.40 \mathrm{oz} /$ ton. Inferred (hypothetical) May Lundy vein resources may exist beyond the limits of the workings. Adjacent to the May Lundy, the Jackson vein (59), which has not been adequately explored, contains at least 7,100 tons of marginal reserve materials that could be incorporated into May Lundy (60) operations. There are also about 50,000 tons of recoverable tailings containing $0.11 \mathrm{oz} /$ ton gold.

George Totland has produced small amounts of gold annually for many years from 39 claims in the Virginia Lakes area (28-31). Reserves on the property consist of as much as 3.1 oz of gold per ton in scattered quartz lenses and pods. Although the tonnage is limited, it is sufficient to maintain a one-man mining operation.

The Gorilla $(38,45)$, Homer $(36,37,42-44)$, Little Emma (54), Page (23,24), Harrison (40), Golden Prince (57), Last Chance (58), and Free Gold (55) mines adjacent to the Hoover Wilderness collectively produced about $\$ 400,000$ in gold $(10,000 \mathrm{oz})$ from small veins containing more than $1 \mathrm{oz}$ per ton. Most known ore shoots are nearly or completely mined out.

The Hess mine (61-63), at the south end of the Hoover Wilderness, contains scheelite whose grade and tonnage are too low to be of interest.

An additional 19 prospects in the area were examined; none of the deposits had resource potential.

\section{Hoover Extension (East) Roadless Area (E4-662)}

The southern part of this area has moderate mineral potential. About 440 claims have been located in and near the area. The Tamarack (12), Dunderberg $(17,20)$, Green Meadow (15), and Ward $(19,21)$ mines were intermittently active in the past and yielded at least $\$ 30,000$ in gold and silver ore. Workings at the Dunderberg mine are caved; however, based on the length of interrupted outcrops of the mineralized fault zone, we estimated 3.5 million tons of gouge and breccia are in the zone. Surface samples contained $0.01 \mathrm{oz} \mathrm{Au} /$ ton and $0.1 \mathrm{oz} \mathrm{Ag} /$ ton; however, ore shoots were mined at moderate depth, and others may exist in unexplored portions of the zone. The structure and composition of veins at the Tamarack mine are unknown; workings are inaccessible and outcrops scarce. Past production and gold-bearing samples from dumps suggest that gold occurred in high-grade pockets. The Green Meadow mine once contained high-grade ( $1 \mathrm{oz} \mathrm{Au} /$ ton and $4 \mathrm{oz} \mathrm{Ag/ton)} \mathrm{ore,} \mathrm{but} \mathrm{known} \mathrm{ore} \mathrm{shoots} \mathrm{are}$ believed to have been mined out. The Ward mine had an unknown amount of production; workings are caved, but assays of veins and dump materials on the surface indicate that high-grade pockets may remain. Additionally, eight prospects in the area were examined and found to have no potential for mineral resources.

\section{Cherry Creek A Roadless Area (5-662)}

This area, which was once a part of the Emigrant Basin Primitive Area, contains a large roof pendant of metasedimentary rocks that is surrounded and intruded by a variety of plutonic bodies. Marble units locally contain epidote-garnet tactites; some contain scheelite. The six claim groups covering the mineralized areas have an estimated 240,000 tons of measured and indicated submarginal tungsten resources and an equal quantity of inferred resources. Their average grade is 0.18 percent tungsten trioxide.

\section{Hoover Extension (West) Roadless Area (W4-662)}

The area has no known occurrences within it; there are two nearby prospects with no observed mineral potential.

\section{Leavitt Lake Roadless Area (4-666)} deposits.

The area has no mineral properties or apparent mineral

\section{GEOLOGY, GEOCHEMISTRY, AND GEOPHYSICS PERTAINING TO MINERAL RESOURCE ASSESSMENT}

The mineral resource potential of the Hoover Wilderness and adjoining roadless areas is estimated from extensive geologic and related information that is summarized in the following sections. Only the most significant data are reflected on the summary map as the basis for areas that may have favorable resource potential.

\section{Geologic setting for mineral deposits}

By Edwin W. Tooker, Gerald F. Brem, James F. Seitz, and William J. Keith

\section{GEOLOGIC TERRANES, STRUCTURES, AND MINERALIZ ATION}

The two main geologic terranes in the study area include a batholithic complex containing metamorphosed sedimentary and volcanic rocks and a younger overlying volcanic sequence that partly conceals the batholithic complex. Areally extensive granitic batholithic rocks consist of numerous plutons, ranging in age from Permian(?) to Tertiary and in composition from quartz diorite to granodiorite and granite. There are also two small gabbro plutons. The granitic plutons were intruded into a sequence of tightly folded metavolcanic and metasedimentary rocks of Paleozoic and Mesozoic age. Known gold deposits in the central and southern parts of the wilderness occur mainly in northwesttrending steeply dipping veins in and near the contacts between plutonic and metasedimentary rocks. The large composite pluton comprised of the Cathedral Peak Granodio-

\footnotetext{
${ }^{5}$ Where gold values were traditionally reported in dollars, we have converted them to troy ounces based on the thencurrent dollar value of metal per ounce.
} 
rite, lying mainly along the west side of the wilderness, is only sparsely altered and pyritized along its extensive joint systems, and, close to its contact, has associated local skarn zones in calcareous metasedimentary rocks. The volcanic rocks of Miocene or younger age include flows, breccias, and lahars that were intruded by dikes and sills and a small granodiorite pluton. These rocks are the remnants of a stratovolcano overlying the ring fracture system of a volcanic caldera. A description of the ages, composition, geometry, and diagnostic characteristics of these rocks is provided on the map by Keith and Seitz (1981) and by Brem (written commun., 1981).

Inferred cross and shear faults occur within or separating plutonic and pendant rocks. Northeast-trending steeply dipping cross faults, or zones which cut across the structure of the metasedimentary rocks, are inferred from apparent offsets of rock units or abrupt changes in the fold structures of roof-pendant rocks, contacts between plutons, linear zones of accelerated erosion and glacial scour, local hot-spring activity, and subtle changes in aeromagnetic patterns. Smaller northwest-trending shear faults in roof pendants generally are subparallel to lithologic contacts locally separating or slicing-out metamorphic units, or occurring in and along contacts with plutonic units. The amount of movement along the Lundy Canyon fault is uncertain, but the offset of pendant strata seems to be right lateral. The inferred Twin Lakes fault coincides with a tongue of the Cathedral Peak Granodiorite in the valley bottom and separates differing sequences of metasedimentary rocks exposed on opposing canyon walls.

The inferred prebatholith(?) Buckeye Creek fault separates the region containing the Little Walker volcanic center and younger associated rocks containing the potential copper-m lybdenum porphyry system from the plutonicmetamorphic terrane to the south. A warm spring also issues from this inferred fault zone. Southwestward projection of this structure across the Sierra Nevada divide into the Cherry Creek drainage area separates batholithic terranes. The main mass of the Cathedral Peak pluton lies south of the projection. North of the line, a generally older plutonic terrane contains locally altered roof pendants. These rock sequences appear to be offset across this inferred line.

\section{ROCKS COMMONLY ASSOCIATED WITH METALLIZATION}

Mineral occurrences seem to be associated mainly with the patterned roof-pendant, plutonic, and volcanic rock units on the map or adjacent to those units. An area of prominent hydrothermal alteration is also patterned. Not all parts of the patterned units are equally well mineralized.

\section{Roof pendants}

Metasedimentary and metavolcanic rocks of late Paleozoic and early Mesozoic age locally are associated with the occurrence of gold and tungsten. In general the main occurrences of gold cluster irregularly about plutons, such as the granodiorite of Mono Dome, and the granodiorite of Green Creek. Quartz-filled veins of the May Lundy mine clearly pass from the granodiorite of Mono Dome into the pendant rocks. The metasedimentary rocks of the Dunderberg Peak area also are veined adjacent to the granodiorite of Green Creek.

The metaconglomerate of Cooney Lake (Keith and Seitz, 1981) in the Cherry Creek area is a rock sequence that contains beds of hornfels, quartzite, and, locally, lenses of carbonate rocks. Where the carbonate beds are in contact with granitic intrusions, they have been altered to skarns that locally contain discontinuous tungsten-bearing and basemetal-bearing lenses (Tooker and others, 1970). Thin carbonate beds of this unit that are located in the southern part of the wilderness north of Lundy Canyon were not in contact with plutonic rocks, and no skarn deposits were formed.

The main tungsten ore horizon in the southeastern part of the study area is in the calc-silicate sequence of Horse Creek (Keith and Seitz, 1981) at the Hess mine (61-63). Steep west-dipping carbonate beds in this unit are in contact with the Cathedral Peak Granodiorite. Mineralizing solutions moved upward along the strike of bedding faults and along shear zones away from the contact, producing skarns in the carbonate beds. In the Twin Peaks area, however, the same unit dips moderately to the east, the carbonate beds are unsheared, and they are only locally in contact with the intrusion. No skarn deposits were formed.

\section{Plutonic rocks}

The granodiorite of Mono Dome and its adjacent wallrocks are hosts for the largest gold-bearing veins in the Lundy Canyon area. The Mono Dome unit is cut by an inferred northeast-trending fault in Lundy Canyon, north of which mineralization in the unit was apparently not as favored as to the south. Indeed, the part of what is herein mapped as the granodiorite of Mono Dome north of the Lundy Canyon fault is Triassic in age and may be correlative with the Wheeler Crest Quartz Monzonite which is present further to the south in the Mount Morrison quadrangle (R. Kistler, oral commun., 1982). The northward limit of significant gold mineralization seems to be related to the area of intrusion of the granodiorite of Green Creek. A few occurrences are associated with pendant rocks along the contact zone. Deposits in the Tamarack mine area may be genetically related to a concealed northward part of this pluton.

Tungsten and minor base-metal-bearing skarns in calcareous metasedimentary rocks are associated with the Cathedral Peak intrusion on the west side of the wilderness.

\section{Volcanic rocks}

Two volcanic units are associated with uranium and molybdenum mineralization. The Relief Peak Formation of Slemmons (1966) of Miocene age, which is mostly composed of lahars, lava flows, and andesite domes, locally has conglomerate-filled basal fluvial channels that contain metamorphic, plutonic, and volcanic detritus. Where these channels contain organic debris, they have locally become sites of uranium deposition in the area west of the wilderness (Tooker and others, 1970; Rapp, 1981). No evidence of such an occurrence has yet been found in the study area.

The Little Walker center northeast of the study area erupted a series of latite flows and tuffs assigned to the Stanislaus Group (Noble and others, 1974). Caldera collapse and infilling was followed by several periods of volcanism along vents in the ring fracture. A large stratovolcano, including Mount Emma, developed along the inferred western ring fracture at the north end of the study area. A series of dikes and subvolcanic intrusions was implaced into the largely pyroclastic stratovolcano and was accompanied locally by hydrothermal argillic and pyritic alteration. This area of dikes and intrusions, which was originally recognized by Brem (written commun., 1981), and which is herein mapped as underlain by the granodiorite of Mount Emma and associated dikes unit, was shown by Keith and Seitz (1981) as underlain by the undivided Stanislaus Group. Geochemical anomalies for base and precious metals (Chaffee, this report) and a geophysical anomaly (Plouff, this report) indicate that alteration and geophysical anomalies may overlie a potential new resource occurrence for copper and molybdenum (Tooker and others, 1981). Definition of a potential deposit will require additional geologic study and subsurface exploration, but the geologic setting suggests that a porphyry or vein copper or molybdenum system may be present.

A number of warm and hot springs are associated with the Little Walker center and Mono craters and with the Buckeye Creek fault and other faults in Bridgeport Valley. These occurrences lie outside the study area; no geothermal energy potential is recognized within the area.

\section{Geochemical anomalies}

By Maurice A. Chaffee

\section{SCOPE OF THE GEOCHEMICAL SAMPLING}

The geochemical samples consisted of three different 
types of materials: whole rock, minus $-0.25-\mathrm{mm}$ stream sediment, and nonmagnetic heavy-mineral concentrate. All were collected at preselected locations; most of the sites for the sediment and concentrate samples were located in firstorder (unbranched) and second-order (below the junction of two first-order) stream channels as defined on 1:62,500-scale topographic maps (Chaffee and others, 1983a-1). A total of 74 rock samples, 182 stream-sediment samples, and 180 nonmagnetic heavy-metal concentrate samples from the study area were analyzed. Additional samples were collected and analyzed for the Leavitt Lake Roadless Area (4-666); these analyses are tabulated in a separate report for the Carson-Iceberg and Leavitt Lake Roadless Areas (Chaffee, unpub. data, 1982). The number of samples analyzed for each medium within the study area yields an approximate sample density of one sample per $3.1 \mathrm{mi}^{2}$ for the rock samples and one sample per $1.3 \mathrm{mi}^{2}$ for the other two types of samples. Plots of the analyses of stream-sediment and concentrate samples identified those drainage basins whose samples contain anomalous concentrations of one or more ore-related elements.

Three types of materials were evaluated to identify normal and anomalous values. The rock samples provide background information on the distribution and abundance of elements in primarily unaltered rock units. Stream-sediment samples are a composite of eroded outcrop material in the drainage basin upstream from each sample site; these samples provide insight to the complex suite of minerals present in a given drainage basin. Nonmagnetic heavy-mineral concentrate samples contain a select group of chemical elements that are not normally determined in stream-sediment samples because of their dilution by quartz, feldspar, clay minerals, and organic materials; these are removed in the concentrating process. Details of the sample collection, preparation, and analysis are provided in Chaffee, Banister, and others (1980), Chaffee, Hill, and others (1980), and Chaffee and others (1983a-1).

Several limitations are implicit in the reconnaissance of stream-basin sampling. Some relatively small but exposed areas containing anomalous concentrations in rock may not have been detected. Also, an unexposed mineral occurrence would not be easily detected even if part of the deposit, such as an alteration aureole, were exposed. Additional detailed geochemical surveys using rock and soil samples, as well as other studies, would be necessary to identify and delineate specific mineralized areas in the overall study area.

\section{GEOCHEMICAL ANOMALIES}

The geochemical survey of the study area reveals localized anomalies for 14 elements ( $\mathrm{Ag}, \mathrm{As}, \mathrm{Au}, \mathrm{B}, \mathrm{Ba}, \mathrm{Bi}$, $\mathrm{Cd}, \mathrm{Cu}, \mathrm{Fe}, \mathrm{Mo}, \mathrm{Pb}, \mathrm{Sb}, \mathrm{W}$, and (or) $\mathrm{Zn}$ ) that may be related to potentially mineralized ground. The most significant anomalies in terms of potential mineral deposits for all three sample media are those found between the Buckeye Creek and the Saddlebag Lake-Warren Fork areas in the southern part of the study area. All of these anomalies seem to be localized within metasedimentary and metavolcanic units of Paleozoic and Mesozoic ages that represent roof pendants within the Sierra Nevada batholith. Small to extensive areas of pervasive hydrothermal alteration are present in outcrops in many of these metamorphosed units.

Within the Hoover Wilderness, the strongest anomalies, in terms of (1) their occurrence in more than one sample media, (2) the number of anomalous elements present, and (3) the highest concentrations for these elements, are located in the area centered on Lundy Canyon. Many of the streamsediment and concentrate anomalies identified by the geochemical survey in the southern part of the area are the result of contamination of the stream channels as a result of past mining activity. Irrespective of this obvious contamination, the overall characteristics of the anomalies for the three sample media suggest that as yet undiscovered mineral deposits (particularly blind deposits) containing any or all of the elements $\mathrm{Ag}, \mathrm{Au}, \mathrm{Cu}, \mathrm{Pb}, \mathrm{Zn}, \mathrm{Cd}, \mathrm{As}, \mathrm{Sb}, \mathrm{Bi}$, and $\mathrm{W}$ may be present within the metamorphic host-rock units.

A number of areas contain overlapping geochemical anomalies for group 1 (probably mineralization related) and group 2 (possibly mineralization related) elements for both stream-sediment and concentrate samples. The sources of most of these anomalies have not been identified, and their significance is not known. Two anomalous areas are particularly significant: (1) areas where known precious-metal mineralization occurs in Lundy Canyon, and (2) the unprospected area immediately northwest of Mount Emma, where metal anomalies coincide with areas of altered rock (Tooker and others, 1981).

Low-level anomalies that are of more restricted areal extent are present in other parts of the study area. The most important of these anomalies includes those in the vicinity of (1) Cherry Creek, (2) upper West Walker River, (3) Molybdenite Creek, and (4) Leavitt Lake. The source of the Mount Emma anomalies, as well as those in other scattered parts of the study area (Chaffee and others, 1983a-1), are not known and deserve further detailed investigation. Low-level anomalies in the Leavitt Lake Roadless Area (4-666) are present for the elements $\mathrm{Bi}, \mathrm{Cu}$, and $\mathrm{Sb}$ in samples of stream sediment and for the elements $\mathrm{Au}, \mathrm{Ba}, \mathrm{Fe}$, and $\mathrm{Pb}$ in samples of nonmagnetic heavy-mineral concentrate. The most significant anomalies for both media are in samples collected from the upper part of the McKay Creek drainage basin. The source of these anomalies is not known; the anomalies may be the result of mineralization or may be caused by contamination from past mining activity. This drainage basin deserves futher detailed investigation. Additional details of the geochemistry of this roadless area are included in geochemical and mineral assessment reports for the CarsonIceberg Roadless Area (M. A. Chaffee, unpub. data, 1982).

\section{Geophysical surveys}

By Donald Plouff

\section{SCOPE OF THE GEOPHYSICAL SURVEYS}

Geophysical surveys included separation of gravity anomaly and magnetic intensity maps (Plouff, 1982a). The gravity survey is a compilation of 86 gravity stations established in 1978 (Plouff, 1982b) and 234 previously established stations (Robbins and Oliver, 1976). The contracted aeromagnetic survey consisted of flight lines flown at a mean altitude of $1,000 \mathrm{ft}$ spaced at intervals of $1 / 2$ mi in the central part of the area and $1 \mathrm{mi}$ near the border (U.S. Geological Survey, 1979). Probable ranges of rock densities and magnetizations assumed for interpretation of the geophysical anomalies were derived mostly from values published for similar kinds of rocks in the surrounding region and were supplemented by a few sample measurements. Further details of geophysical data collection, compilation, and interpretation in the Hoover Wilderness and adjoining roadless areas are provided in Plouff (1982a).

\section{SIGNIFICANCE OF GEOPHYSICAL FEATURES}

The gravity anomaly map (Plouff, 1982a) reflects lateral changes in the density of the underlying rocks. The southwestern one-third of the map area is dominated by nearly linear northwest-trending contours that mostly reflect a regional zone of northeastward thickening of the crust and the effect of a root beneath the Sierra Nevada. The associated large regional gravity gradient obscures anomalies associated with near-surface density distributions that might be related to ore deposition. The source of a prominent gravity low at Twin Lakes in the central part of the area is unknown, but the anomaly seems to reflect the density contrast between underlying plutonic rocks and metamorphic rocks to the north and south. A north-northwest-trending elongated gravity high in the southern part of the area overlies a belt of metamorphic roof-pendant rocks surrounded by less dense plutonic rocks. The prominent gravity low located near the northeast corner of the area reflects the low density of the tuffs and sedimentary deposits that fill the Little Walker caldera (Noble and others, 1974).

The magnetic intensity map (Plouff, 1982a) shows great diversity in the magnetization of the underlying rocks along the east flank of the Sierra Nevada. The magnetic 
pattern is further complicated by strong topographic effects in this area of rugged relief. The metasedimentary rocks and sedimentary deposits have little or no magnetization. Most plutonic rocks have low to moderate magnetization in this area. Several plutons, however, have relatively high magnetization, as indicated by sample measurements and by associated magnetic highs. The level of magnetization in metavolcanic rocks is variable within mapped units as well as relative to surrounding rocks, according to interpretation of the magnetic pattern. Tertiary volcanic rocks have widely varying magnetizations including reversed remanent magnetization that causes associated magnetic lows.

Though the magnetic pattern is very complex, there is good correlation between the magnetic intensity map and the mapped geologic units (Plouff, 1981). The magnetic intensity map is useful for indicating continuations of magnetic trends related to existing mineral prospects and geochemical anomalies.

\section{GEOPHYSICAL EXPLORATION TRENDS}

Interpretation of these data show that the geophysical anomaly patterns at five localities (fig. 2) may delineate areas for more detailed exploration.

(1) A prominent gravity high and a somewhat discontinuous belt of magnetic lows trend north-northwest through Saddlebag Lake near the southeast corner of the area. The anomaly primarily reflects high density and lower magnetization of the underlying belt of metasedimentary roof-pendant rocks compared to surrounding plutonic rocks.

(2) The May Lundy (60) and adjacent mines in the Homer district occur along the broad east flank of a northtrending gravity high. Farther southeast, the Log Cabin (65) mine occurs in a magnetic low, which forms part of a ring of polarization lows along the north flank of a magnetic high and an associated gravity high to the south.

(3) The Tamarack mine area, located southeast of Twin Lakes and east of the study area, occurs in metasedimentary rocks within gradients along the south edges of east- and northeast-trending magnetic and gravity lows, respectively.

(4) The mines in the Cherry Creek area occur along the same prominent magnetic gradient. The gradient in part follows the trend of an elongated metaconglomerate unit and its contact with plutonic rocks to the northwest.

(5) Moderate gravity and strong magnetic highs are centered near Mount Emma in the northern part of the area. The magnitude of the geophysical anomalies suggests that igneous rocks associated with this eruptive center may extend several miles beneath the surface.

\section{EXPLANATION OF CRITERIA FOR, AND AREAS OF, MINERAL RESOURCE POTENTIAL}

Mineral resource pot tial in the wilderness and roadless areas is ranked into four classes (fig. 3 ), from I, favorable to IV, unfavorable. Ranking is based on the following criteria: I, favorable-Areas with a combination of resource attributes such as the presence of several productive deposits, the possibility for developing extensions of those deposits, outcrop exposures of ore minerals, fresh and altered host rocks and associated structures commonly occurring with ore deposits elsewhere, and strong geochemical and geophysical anomalies. II, moderately favorable or untestedAreas with a few small deposits or mineralized prospects and a minimal combination of geologic, geochemical, and geophysical attributes sufficient for proposing a potential new mineral occurrence. III, low or limited favorability-Areas with few if any prospects and only minor indications of favorable geologic attributes, or with geologic structures that preclude extension of surface mineral deposits to sufficient depth for development. IV, unfavorable-Those remaining geologic terranes containing none of the favorable attributes that would provoke suspicion that an undiscovered mineral deposit is present.

On the basis of this study, mineral resource potential is considered to be favorable ( 1 ) in one area, moderately favorable or untested (II) in three areas, to have low or limited favorability (III) in eight areas, and unfavorable (IV) in the remaining areas. Each of these areas and the specific criteria for their ranking are summarized in table 1.

The Lundy Canyon area, located partly within the southern tip of the wilderness, is ranked as having favorable (I) mineral resource potential for gold deposits. The area, which encompasses most of the pluton comprised of the granodiorite of Mono Dome, contains geochemical anomalies of A1, A2, B1, and B2 types (fig. 3). A large number of mines are present in this area, including the May Lundy (60), which produced most of the gold from within the wilderness. An inferred northeast-trending fault in Lundy Canyon that cuts. the Mono Dome unit divides the unit into areas apparently favorable (south) and unfavorable (north) to mineralization.

Two areas are considered to have moderately favorable or untested (II) resource potential for gold. The Virginia Pass area, located in the southern part of the wilderness, has geochemical anomalies of the A1, B1, B2, and C types, and several mines. The Green Creek area is east of the Virginia Lakes area and is partly in the wilderness and partly in the Hoover Extension (East) Roadless Area. The area includes most of the pluton designated as the granodiorite of Green Creek, as well as the Monument Ridge area that has geochemical anomalies of the $\mathrm{A} 1$ and $\mathrm{B} 1$ types. in area of moderately favorable or untested (II) potential for copper and molybdenum occurs near Mount Emma in the northern part of the study area. The region encompasses the pluton comprised of the granodiorite of Mount Emma, hydrothermally and propylitically altered volcanic and intrusive rocks, and Tertiary volcanic rocks. Geochemical anomalies of the A2, B1, B2, and C types are also present. Further investigations are needed before the copper-molybdenum potential of this area is substantiated.

Three areas have low or limited favorability (III) for tungsten resources. The Cherry Creek area is the most significant of the three and is roughly coincident with a roof pendant of metasedimentary rocks. Six scheelite claims in the area have estimated resources of 480,000 tons (table 2). The Bonnie Lake area is located just northeast of Cherry Creek area and contains geochemical anomalies of the A1 and A2 types. The third tungsten area is the Hess mine area, in the southern tip of Hoover Wilderness. The area includes a narrow strip of metasedimentary rocks and is considered to have limited resource potential (table 2).

Four areas have low or limited (III) favorability for gold. These are the Tioga Pass area, just outside of the southern tip of the wilderness, the Tamarack area in Hoover Extension (East) Roadless Area, the Upper Twin Lake area that coincides with geochemical anomalies of the A1 and B1 types, and the Leavitt Lake area in the Leavitt Lake Roadless Area, which coincides with an area of A1, B1, and C type geochemical anomalies.

Lastly, the Walker Mountain area has low or limited favorability (III) resource potential for copper and molybdenum. The area coincides with geochemical anomalies of the $\mathrm{A} 2$ and $\mathrm{C}$ types.

The remaining areas in the wilderness and adjoining roadless areas are considered to have unfavorable (IV) mineral resource potential.

\section{REFERENCES CITED}

Bateman, P. C., and Wahrhaftig, Clyde, 1966, Geology of the Sierra Nevada, in Bailey, E. H., ed., Geology of northern California: California Division of Mines and Geology Bulletin 190, p. 107-172.

Brook, C. A., 1977, Stratigraphy and structure of the Saddlebag Lake roof pendant, Sierra Nevada, Calif.: Geological Society of America Bulletin, v. 88, p. 321334.

Chaffee, M. A., Banister, C. A., Barnard, J. B., Guisso, J. R., Hill, R. H., Keith, W. J., Seitz, J. F., Speckman, W. S., and Sutley, S. J., 1980, Geochemical analyses of samples of rock, stream sediment, and panned heavymineral concentrate, Hoover Wilderness and adjacent study areas, California: U.S. Geological Survey OpenFile Report 80-79, 39 p.

Chaffee, M. A., Hill, R. H., Speckman, W. S., and Sutley, S. J., 1980, Preliminary data set containing geochemical 
analyses of samples of rock, stream sediment, and nonmagnetic heavy-mineral concentrate, Walker Lake $2^{\circ}$ quadrangle, California and Nevada: U.S. Geological Survey Open-File Report 80-881, 235 p.

Chaffee, M. A., Hill, R. H., and Sutley, S. J., 1983a, Distributions of silver in samples of minus $-0.25-\mathrm{mm}$ stream sediment and nonmagnetic heavy-mineral concentrate and of gold in nonmagnetic heavy-mineral concentrate, Hoover Wilderness and adjacent study area, Mono and Tuolumne Counties, California: U.S. Geological Survey Open-File Report 82-283-A, scale $1: 62,500$ in press .

$1983 \mathrm{~b}$, Distributions of copper in samples of minus-0.25$\mathrm{mm}$ stream sediment and nonmagnetic heavy-mineral concentrate, Hoover Wilderness and adjacent study area, Mono and Tuolumne Counties, California: U.S. Geological Survey Open-File Report 82-283-B, scale $1: 62500$ in press.

$1983 \mathrm{c}$, Distributions of lead in samples of minus-0.25-mm stream sediment and nonmagnetic heavy-mineral concentrate, Hoover Wilderness and adjacent study area, Mono and Tuolumne Counties, California: U.S. Geological Survey Open-File Report 82-283-C, scale $1: 62,500$ in press

1983d, Distributions of zinc and cadmium in samples of minus $-0.25-\mathrm{mm}$ stream sediment, Hoover Wilderness and adjacent study area, Mono and Tuolumne Counties, California: U.S. Geological Survey Open-File Report 82-283-D, scale $1: 62,500$ in press.

1983 e, Distributions of arsenic in samples of minus-0.25$\mathrm{mm}$ stream sediment and nonmagnetic heavy-mineral concentrate, Hoover Wilderness and adjacent study area, Mono and Tuolumne Counties, California: U.S. Geological Survey Open-File Report 82-283-E, scale $1: 62,500$ in press .

$1983 \mathrm{f}$, Distributions of antimony and bismuth in samples of minus $-0.25-\mathrm{mm}$ stream sediment, Hoover Wilderness and adjacent study area, Mono and Tuolumne Counties, California: U.S. Geological Survey Open-File Report $82-283-\mathrm{F}$, scale $1: 62,500$ in press .

$1983 \mathrm{~g}$, Distributions of boron in samples of minus$0.25-\mathrm{mm}$ stream sediment and nonmagnetic heavy-mineral concentrate, Hoover Wilderness and adjacent study area, Mono and Tuolumne Counties, California: U.S. Geological Survey Open-File Report $82-283-G$, scale $1: 62,500$ in press .

$1983 \mathrm{~h}$, Distributions of molybdenum in samples of minus$0.25-\mathrm{mm}$ stream sediment and nonmagnetic heavy-mineral concentrate, Hoover Wilderness and adjacent study area, Mono and Tuolumne Counties, California: U.S. Geological Survey Open-File Report $82-283-\mathrm{H}$, scale $1: 62,500$ in press .

1983i, Distributions of tungsten and tin in samples of nonmagnetic heavy-mineral concentrate, Hoover Wilderness and adjacent study area, Mono and Tuolumne Counties, California: U.S. Geological Survey Open-File Report $82-283-I$, scale $1: 62,500$ in press .

$1983 \mathrm{j}$, Distributions of barium in samples of minus-0.25$\mathrm{mm}$ stream sediment and nonmagnetic heavy-mineral concentrate, Hoover Wilderness and adjacent study area, Mono and Tuolumne Counties, California: U.S. Geological Survey Open-File Report 82-283-J, scale $1: 62,500$ in press

$1983 \mathrm{k}$, Distributions of thorium and iron in samples of nonmagnetic heavy-mineral concentrate, Hoover Wilderness and adjacent study area, Mono and Tuolumne Counties, California: U.S. Geological Survey Open-File Report $82-283-K$, scale $1: 62,500$ in press .

19831, Summary geochemical maps, Hoover Wilderness and adjacent study area, Mono and Tuolumne Counties, California: U.S. Geological Survey Miscellaneous Field Studies Map MF-1101-B, 3 sheets, scale $1: 62,500$ in press .

Chesterman, C. W., 1975, Geology of the Matterhorn Peak 15-minute quadrangle, Mono and Tuolumne Counties, California: Sacramento, California Division of Mines and Geology, scale 1:62,500.

DeDecker, Mary, 1966, Mines of the eastern Sierra Nevada: Glendale, Calif., La Siesta Press, 72 p.

Evernden, J. F., and Kistler, R. W., 1970, Chronology and emplacement of Mesozoic batholithic complexes in California and western Nevada: U.S. Geological Survey Professional Paper 623, 42 p.

Keith, W. J., and Seitz, J. F., 1981, Geologic map of the Hoover Wilderness and adjacent study area, Mono and Tuolumne Counties, California: U.S. Geological Survey Miscellaneous Field Studies Map MF-1101-A, scale 1:62,500.

Kistler, R. W., 1966, Geologic map of the Mono Craters quadrangle, Mono and Tuolumne Counties, California: U.S. Geological Survey Geologic Quadrangle Map GQ-462, scale 1:62,500.

Noble, D. C., Slemmons, D. B., Korrings, M. K., Dickinson, W. R., Al-Rawi, Yehya, and McKee, E. H., 1974, Eureka Valley tuff, east-central California and adjacent Nevada: Geology, v. 2, no. 3, p. 139-142.

Plouff, Donald, 1382a, Map showing gravity and magnetic surveys of the Hoover Wilderness and adjacent study area, Mono and Tuolumne Counties, California: U.S. Geological Survey Miscellaneous Field Studies Map MF-1101-C, scale $1: 62,500$.

1982b, Gravity observation in the Walker Lake 1, x 2 , quadrangle, California-Nevada: U.S. Geological Survey Open-File Report 82-405, 105 p.

Rapp, J. S., 1981, Uranium mineralization of the Sonora Pass region, Tuolumne County, Calif.: California Geology, v. 34 , p. $43-52$.

Robbins, S. L., and Oliver, H. W., 1976, Principal facts, accuracies, sources, descriptions, and plots of 832 gravity stations on the Walker Lake $1^{\circ} \times 2^{\circ}$ quadrangle, California and Nevada: Springfield, Virginia, U.S. Department of Commerce, National Technical Information Series no. PB-251-249, 43 p.

Silberman, M. L. and MeKee, E. H., 1977, A summary of radiometric age determinations on Tertiary volcanic rocks from Nevada and eastern California, Pt. II western Nevada: Isochron/West, no. 4, p. 7-28.

Slemmons, D. B., 1966, Cenozoic volcanism of the central Sierra Nevada, California, in Bailey, E. H., ed., Geology of northern California: California Division of Mines and Geology Bulletin 190, p. 199-208.

Tooker, E. W., Brem, G. F., Chaffee, M. A., and Plouff, Donald, 1981, A potential resource target identified in the Hoover Wilderness and adjoining RARE II study areas, California: U.S. Geological Survey Open-File Report 81-788, 7 p.

Tooker, E. W., Morris, H. T., and Fillo, P. V., 1970, Mineral resources of the Emigrant Basin primitive area, California: U.S. Geological Survey Bulletin 1261-G, $70 \mathrm{p}$.

U.S. Geological Survey, 1979, Aeromagnetic map of the Hoover-Walker Lake area, California: U.S. Geological Survey Open-File Report 79-1194, scale 1:250,000.

Zietz, Isidore and Kirby, J. R., 1960, Transcontinental geophysical survey $\left(35^{\circ}-39^{\circ}\right.$ N.) magnetic map from $112^{\circ}$ W. longitude to the coast of California: U.S. Geological Survey Miscellaneous Geologic Investigations Map I-532A, scale $1: 1,000,000$.

Zilka, N. T., and Leszcykowski, A. M., 1982, Mineral resources of the Hoover Wilderness and proposed RARE II additions 4-662, 5-662, 4-666, Mono and Tuolumne County California: U.S. Bureau of Mines Mineral Land Assessment Report MLA 49-82 13 p. 


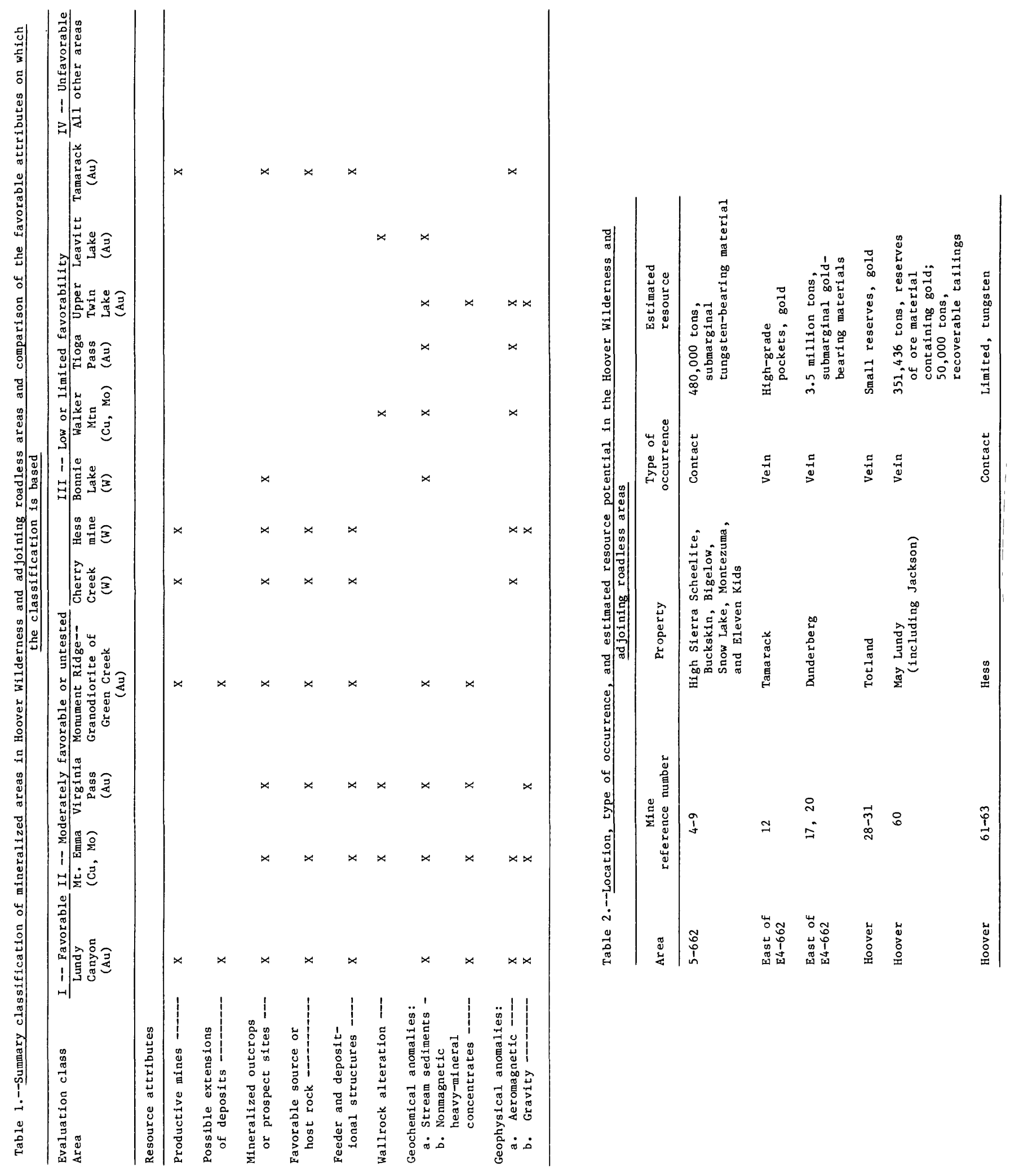




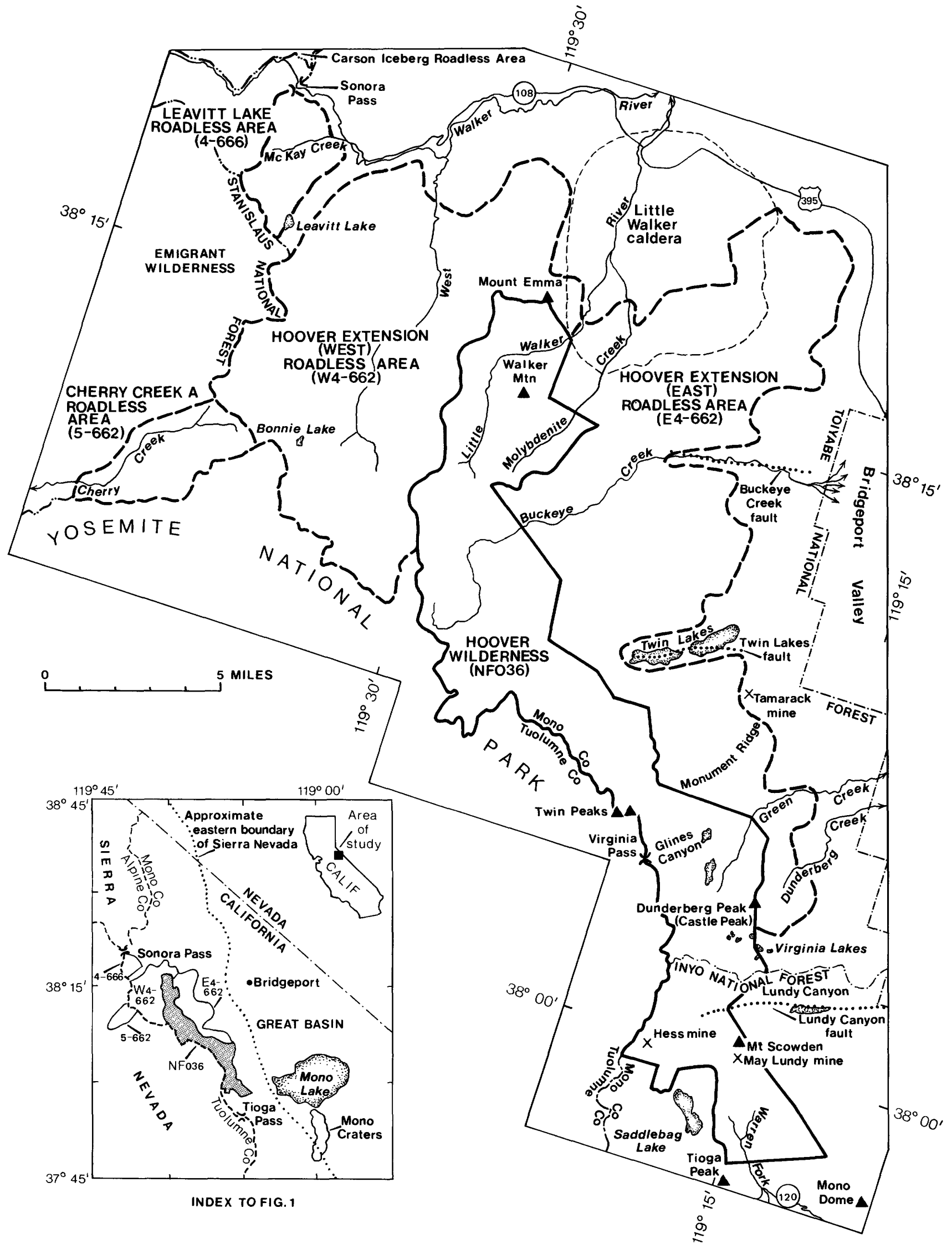

Figure 1.--Index map of Hoover Wilderness and adjacent roadless areas, central Sierra Nevada, California. 


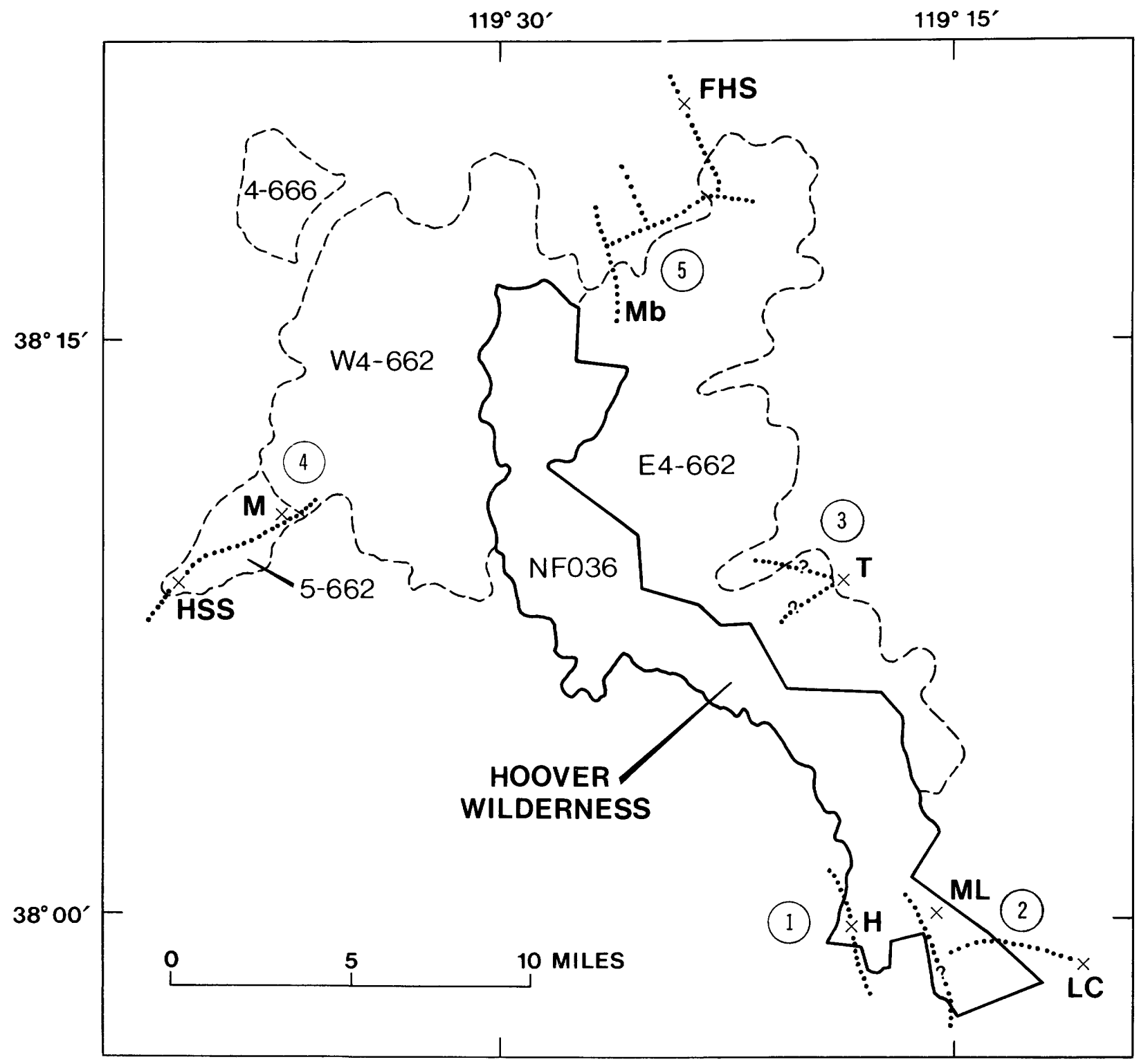

Figure 2.--Index map showing possible sites for prospecting, based on geophysical trends near existing mines and hot springs. HSS, High Sierra Scheelite; FHS, Fales Hot Springs; H, Hess mine; LC, Log Cabin mine; M, Montezuma mine; Mb, Molybdenite Creek; ML, May Lundy mine; and $T$, Tamarack mine. Solid line indicates boundary of Hoover Wilderness. Dashed line indicates boundary of study area. Dotted lines indicate geophysical trends potentially favorable to prospecting. Numbers refer to areas discussed in text. 


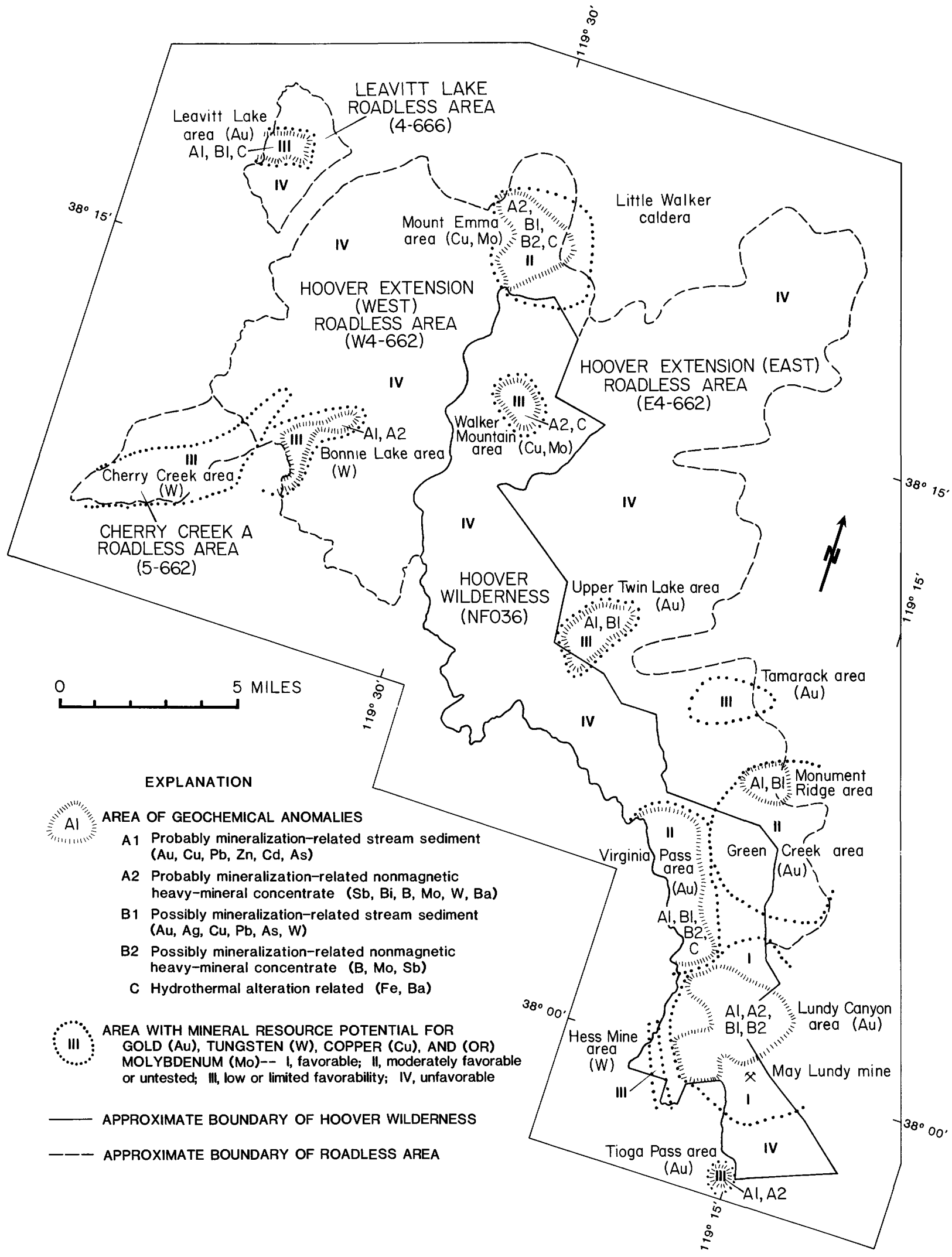

Figure 3.--Mineral resource potential map of Hoover Wilderness and adjacent roadless areas. 
$\bullet$
$\cdot$
$\bullet$

1

1

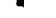

